NUKHBATUL 'ULUM : Jurnal Bidang Kajian Islam

Vol. 4, No. 2 (2018) : Hal. 145-152

Website: https://journal.stiba.ac.id

ISSN : 2685-7537 (online) 2338-5251 (Printed)

\title{
SEJARAH LEMBAGA PENDIDIKAN ISLAM DI INDONESIA SEBELUM KEMERDEKAAN (ABAD 7 DAN 8 MASEHI)
}

\section{Iskandar}

\author{
Sekolah Tinggi Ilmu Islam dan Bahasa Arab (STIBA) Makassar \\ Email : iskandarkato28@gmail.com
}

\begin{abstract}
Keywords :
ABSTRACT

Islamic Education, History of The history of Islam inscribed on the archipelago is actually inseparable Islam, Islamization from the development of Islamic education in Indonesia. To be precise,
the development of Islamic education has an age that is almost the same
as the history of Islamic travel in Indonesia. The history of Islamic
education is as old as the entry of Islam into Indonesia. This is because
the followers of Islam who were still relatively new at that time, will
certainly learn and understand about the teachings of Islam. Even
though in a simple sense, the learning process that time had happened.
From here, Islamic education began to emerge. Where at first they
studied in homes, langgar/ surau, mosques and later developed into
boarding schools. The development of Islam in the Arabian Peninsula
in the 7 th century has implications for the spread of Islam to various
parts of the world with several channels of the Islamization process in
Indonesia, namely, trade, marriage, art, and education.
\end{abstract}


NUKHBATUL 'ULUM : Jurnal Bidang Kajian Islam

Vol. 4, No. 2 (2018) : Hal. 145-152

Website: https://journal.stiba.ac.id

ISSN : 2685-7537 (online) 2338-5251 (Printed)

\section{PENDAHULUAN}

Proses masuknya Islam di Nusantara, banyak memunculkan debatable di kalangan sejarawan. Perdebatan ini menurut Sunanto dikarenakan orang-orang yang terlibat dalam kegiatan dakwah pada masa awal tersebut tidak bertendensi apapun selain bertanggung jawab dan menunaikan kewajiban. ${ }^{1}$ Dengan demikian sangat wajar kemudian jika para aktor sejarah ketika itu tidak membuat catatan sejarah yang mengabadikan peran mereka dalam perjalanan sejarah Islam di Nusantara. Untuk menganalisis masuknya pendidikan Islam di Indonesia, maka sangat tepat kiranya jika menelusuri proses masuknya Islam di bumi Nusantara tersebut, sebab pendidikan Islam di Indonesia memiliki perjalanan sejarah yang sama dengan sejarah masuknya Islam di Indonesia. Informasi tentang Islam di bumi Nusantara telah diterima sejak orang Vanesia (Italia) yang bernama Marcopolo singgah di kota Perlak dan menerangkan bahwa sebagian besar penduduknya telah beragama Islam. ${ }^{2}$ Namun yang menjadi persoalan kemudian adalah kapan tepatnya Islam masuk ke Indonesia. Persoalan ini muncul akibat tidak adanya catatan sejarah yang menjelaskan secara otentik prosesi masuknya Islam di Indonesia

Jejak sejarah yang ditorehkan Islam di Bumi Nusantara sesungguhnya tidak bisa dipisahkan dari perkembangan pendidikan Islam

\footnotetext{
1 Musyrifah Sunanto, Sejarah Peradaban Islam Indonesia, (Jakarta: PT. Raja Grafindo Persada, 2005, h. 8

2Depag RI Dirjen Kelembagaan Agama Islam, Rekonstruksi Sejarah Pendidikan Islam di Indonesia, Jakarta, 2005, h. 41
}

di Indonesia. ${ }^{3} \quad$ Tepatnya, perkembangan pendidikan Islam memiliki usia yang hampir sama dengan sejarah perjalanan Islam di Indonesia, bahkan dalam konteks ini, Mahmud Yunus mengatakan, bahwa sejarah pendidikan Islam sama tuanya dengan masuknya Islam ke Indonesia. Hal ini disebabkan karena pemeluk agama Islam yang kala itu masih tergolong baru, maka sudah pasti akan mempelajari dan memahami tentang ajaran-ajaran Islam. Meski dalam pengertian sederhana, namun proses pembelajaran waktu itu telah terjadi. Dari sinilah kemudian mulai timbul pendidikan Islam. Di mana pada mulanya mereka belajar di rumahrumah, langgar/surau, masjid dan kemudian berkembang menjadi pondok pesantren. ${ }^{4}$

Dalam perjalanannya, Pendidikan Islam di Indonesia telah melalui tiga tahapan. Tahapan pertama berlangsung pada awal masuknya Islam di Indonesia. Periode ini ditandai dengan perkembangan pesantren. Sementara tahapan kedua berlangsung semenjak munculnya ide-ide pembaharuan yang ditandai dengan lahirnya madrasah kemudian selanjutnya tahapan yang ketiga pendidikan Islam telah terintegrasi ke dalam sistem pendidikan nasional sejak lahirnya UndangUndang Nomor 2 Tahun 1989 dilanjutkan dengan Undang-Undang No. 20 Tahun $2003 .{ }^{5}$

${ }^{3}$ http://www.canboyz.co.cc/2010/02/pen didikan-Islam.html

${ }^{4}$ http://limalaras.wordpress.com/2011/0 1/31/asal-usul-pendidikan-Islam-di-indonesia/

${ }^{5}$ http://id.shvoong.com/books/dictionary 2020367-sejarah-pertumbuhan-danpembaruan-pendidikan/\#ixzz1/wJBBcfv 
Berdasarkan latar belakang di atas maka tulisan ini fokus kepada Rumusan masalah sebagai berikut:

1. Perkembangan lembaga pendidikan Islam di Indonesia pada zaman penjajahan sekitar abad 7 dan 8 Masehi?

2. Apa kontribusi Pendidikan Islam Abad 7 dan 8 Masehi dalam Islamisasi ?

\section{PEMBAHASAN}

\section{Lembaga Pendidikan Islam Abad 7 dan 8 Masehi}

Pendidikan mempunyai arti penting bagi kehidupan, karena dapat membantu manusia dalam mencapai kemajuan. Pendidikan yang tepat telah mendorong Islam mencapai kejayaannya pada masa klasik, begitu pula pendidikan yang kurang tepat membawa kemunduran Islam pada masa belakangan. Karena itu, jika umat Islam ingin maju, pendidikannya mestilah dibenahi. Dan pembenahan ini hanya dapat dilakukan manakala umat Islam memahami sejarah pendidikannya sendiri.

Oleh karena itu, berbicara tentang Pendidikan Islam di Nusantara tidak dapat dipisahkan dari sejarah penyebaran dan perkembangan umat Islam di bumi nusantara. Islam masuk ke Indonesia pada abad VII M. dan berkembang pesat sejak abad VIII M dengan munculnya kerajaan-kerajaan Islam, maka pendidikan Islam juga mengalami perkembangan seiring dengan dinamika perkembangan Islam. Di mana saja di Nusantara ini terdapat komunitas umat Islam, maka di sana juga terdapat aktivitas pendidikan

${ }^{6}$ Hasbullah, Sejarah Pendidikan Islam di Indonesia; Lintas Sejarah Pertumbuhan dan Perkembangan (Cet.III; Jakarta: PT. Raja Grafindo Persada, 1999), h. 5.
Islam. Sistem pendidikan Islam ketika itu dilaksanakan sesuai dengan situasi dan kondisi lokal di mana kegiatan pendidikan itu dilaksanakan. ${ }^{6}$

Persoalan lain yang menjadi masalah dalam melacak pengajaran Islam di Nusantara adalah tentang siapa yang memperkenalkan Islam ke Nusantara. Karena itu muncul teori bahwa Islam dibawa ke Nusantara oleh para pedagang. Teori lain menyatakan bahwa Islam tersebar di Indonesia oleh para ulama (mulla). Sedangkan teori ketiga menyatakan bahwa kekuasaan (konversi) keraton sangat berpengaruh bagi pengislaman di Nusantara. Masuknya Islam penguasa akan diikuti oleh rakyatnya secara cepat. ${ }^{7}$

Pada sekitar abad ke-7 dan 8, pada saat Kerajaan Sriwijaya mengembangkan kekuasaannya, selat Malaka sudah dimulai dilalui oleh pedagang-pedagang muslim dalam pelajarannya ke negeri-negeri di Asia Tenggara dan Asia Timur.

Islam pertama kali masuk ke Indonesia adalah di Sumatera. Sedangkan Islam masuk ke Jawa waktunya di duga kuat berdasarkan batu nisan kubur Fatimah binti Maimun di Leran (Gresik). Situasi politik mempercepat penyebaran Islam di Jawa, pada saat melemahnya Majapahit karena perpecahan. Bupatibupati pesisir yang memeluk agama Islam, agama menjadi kekuasaan terbaru dalam proses perkembangan masyarakat.

Seiring dengan perkembangan Islam di wilayah Sumatera dan Jawa maka dimulai pula pendirian lembaga pendidikan Islam sebagai upaya untuk penanaman nilai-nilai Islam kepada

${ }^{7}$ Hanun Asrohah, Sejarah Pendidikan Islam (Cet. II; Jakarta: Logos Wacana IImu, 2001), h. 141. 
masyarakat. Ada beberapa lembaga pendidikan Islam awal yang muncul di Indonesia diantaranya:

\section{Masjid dan Langgar}

Masjid fungsi utamanya adalah untuk tempat shalat yang lima waktu ditambah dengan sekali seminggu dilaksanakan shalat jum'at dan dua kali setahun dilaksanakan shalat hari raya Idul fitri dan Idul Adha. Selain dari masjid ada juga tempat ibadah yang disebut langgar, bentuknya lebih kecil dari masjid dan digunakan hanya tempat shalat lima waktu, bukan untuk tempat shalat jum'at.

Selain dari fungsi utama masjid dan langgar difungsikan juga untuk tempat pendidikan. Di tempat ini dilakukan pendidikan buat oreng dewasa adalah penyampaianpenyampaian ajaran Islam oleh mubaligh kepada para jama'ah dalam bidang yang berkenaan dengan akidah, ibadah dan akhlak.

Sedangkan pengajian untuk anak-anak berpusat kepada pengajian Al-Qur'an menitik beratkan kepada kemampuan membacanya dengan baik sesuai dengan kaedah-kaedah bacaan dan juga diberi pendidikan keimanan ibadah dan akhlak. ${ }^{8}$

2. Pesantren

Ditinjau dari segi sejarah, belum ditemukan data sejarah, kapan pertama sekali berdirinya pesantren, ada pendapat mengatakan bahwa pesantren telah tumbuh sejak awal masuknya Islam ke Indonesia, sementara yang lain berpendapat bahwa pesantren baru muncul pada masa Walisongo dan Maulana Malik Ibrahim dipandang senangi orang yang pertama mendirikan pesantren.

Inti dari pesantren itu adalah pendidikan ilmu agama, dan sikap

\footnotetext{
${ }^{8}$ http://id.wikipedia.org/wiki/sejarah_Ind onesia
}

beragama. Karenanya mata pelajaran yang diajarkan semata-mata pelajaran agama. Pada tingkat dasar anak didik baru diperkenalkan tentang dasar agama, dan Al-Qur'an Al-Karim. Setelah berlangsung beberapa lama pada saat anak didik telah memiliki kecerdasan tertentu, maka mulailah diajarkan kitab-kitab klasik. Kitab-kitab klasik ini juga diklasifikasikan menjadi tingkat dasar, tingkat menengah dan tinggi.

3. Meunasah, Rangkang dan Dayah

Secara epistemologi meunasah berasal dari perkataan madrasah, tempat belajar atau sekolah. Ditinjau dari segi pendidikan awal bagi anakanak yang dapat disamakan dengan tingkatan sekolah dasar. Dimeunasah diajarkan menulis, membaca huruf arab, almu agama dan ilmu bahasa Jawi, akhlak. Di tinjau dari segi pendidikan, meunasah adalah lembaga pendidikan awal bagi anak-anak yang dapat disamakan dengan tingkatan sekolah dasar. Di meunasah para murid di ajar menulis, membaca huruf Arab, ilmu agama, dan akhlaq. Meunasah dipimpin oleh seorang tengku, yang di Aceh besar disebut tengku meunasah. Tengku meunasah bertugas untuk membina agama di suatu tempettempat tertentu.

Rangkang adalah tempat tinggal murid, yang dibangun disekitar masjid. Tiap-tiap kampung harus ada satu meunasah. Masjid berfungsi sebagai tempat kegiatan pendidikan. Pendidikan di Rangkang ini terpusat kepada pendidikan agama, disini telah diajarkan kitab-kitab yang berbahasa arab. Tingkat pendidikan ini jika dibandingkan dengan sekolah saat sekarang setingkat sekolah lanjutan pertama.

${ }^{9}$ Zuhairini, Sejarah Pendidikan Islam (Jakarta: Bumi Aksara, 2000), h.136 
Sistem pendidikan di Rangkang ini sama dengan sistem pendidikan di Pesantren, murid-murid duduk membentuk lingkaran dan guru menerangkan pelajaran, berbentuk halakah, metode yang disampaikan di dunia pesantren disebut dengan wetonan dan sorogan. ${ }^{10}$

Dayah berasal dari bahasa Arab zawiyah. Kata zawiyah pada mulanya merujuk kepada sudut dari satu bangunan, dan sering di kaitkan dengan masjid. Disudut masjid itu terjadi proses pendidikan antada pendidik dengan terdidik. Selanjutnya zawiyah dikaitkan tarekat-tarekat sufi, dimana seorang syekh atau mursyid melakukan kegiatan pendidikan kaum sufi.

Dayah adalah sebuah lembaga pendidikan yang mengajarkan mata pelajaran agama yang brsumber dari bahasa arab, misalnya fiqih, bahasa Arab, Tauhid, tasawuf, dll, tingkat pendidikannya adalah sama dengan tingkat Sekolah Lanjutan Tingkat Atas.

4. Surau

$$
\text { Dalam Kamus Bahasa }
$$

Indonesia, surau diartikan tempat (rumah) umat Islam melakukan ibadahnya (bersembahyang, mengaji, dan sebagainya) pengertian ini apabila dirinci mempunyai arti bahwa surau berati suatu tempat bengunan kecil untuk tempat shalat, tempat belajar mengaji anak-anak, tempat wirid (pengajian agama) bagi orang dewasa.

Perkataan surau menyebar luas di Indonesia dan Malaysia, yang dalam kehidupan keseharian adalah suatu bangunan kecil yang penggunaan utamanya untuk shalat berjamaah bagi masyarakat sekitar.

Surau berfungsi sebagai lembaga sosial budaya, adalah fungsinya sebagai tempat pertemuan

10Zuhairini, Sejarah Pendidikan Islam, h.142 para pemuda dalam upaya mensosialisasikan diri mereka. Selain dari itu surau juga berfungsi sebagai tempat bersinggahan dan peristirahatan para musafir yang sedang menempuh perjalanan.

Sistem pendidikan di surau banyak kemiripannya dengan sistem pendidikan di Pesantren. Murid tidak terikat dengan sistem administrasi yang ketat, Syekh atau Guru mengajar dengan murid yang berpindah ke surau lain apabila dia telah merasa cukup memperoleh ilmu di surau terdahulu.

Di Sumatera barat pengertian surau tidak hanya berfungsi kepda beberapa fungsi yang disebutkan diatas,tetapi lebih luas dari itu lagi. Surau bagi masyarakat minangkabau tidak hanya mempunyai fungsi pendidikan dan ibadah, tetapi lainnya juga mempunyai fungsi budaya.

Surau berfungsi sebagai lembaga sosial buadaya,adalah fungsinya sebagai tempat pertemuan para pemuda dalam upaya mensosialisasikan diri mereka. Selain dari itu surau juga berfungsi sebagai tempat persinggahan dan peristirahatan para musafir yang sedang menempuh perjalanan. Dengan demikian surau mempunyai multifungsi. ${ }^{11}$

Di dalam referensi lain dijelaskan pula oleh Azyumardi Azra' bahwa surau juga menjadi tempat persinggahan bagi musafir dan sebagainya yang sedang melalui suatu desa.

Dengan masuknya islam, surau juga mengalami proses islamisasi. Fungsinya sebagai tempat penginapan anak-anak bujang tidak berubah, tetapi fungsinya diperluas seperti fungsi masjid, yaitu sebagai tempat belajar

\footnotetext{
11Zuhairini, Sejarah Pendidikan Islam,
} 
membaca Al-Qur'an dan dasar-dasar agama dan tempat ibadah.

\section{Kontribusi Pendidikan Islam Abad 7 dan 8 Masehi dalam Islamisasi}

Perkembangan Islam di Jazirah Arab pada abad ke-7 Masehi membawa implikasi penyebaran agama Islam ke berbagai belahan dunia. Islamisasi mengalami proses yang masif sejak awal kemunculannya. Salah satunya terkait doktrin agama yang menganjurkan setiap individu menyampaikan ajaran agamanya kepada siapapun.

\section{Dengan}

terbentuknya

komunitas atau masyarakat muslim pada beberapa daerah di Indonesia ini, mendorong untuk membentuk kerajaan Islam sebagai pusat kekuatan atau kekuaaan politik didalam proses Islamisasi di Indonesia. Maka berdirilah kerajaan-kerajaan Islam seperti Samudera Pasai dan Perlak di Aceh pulau Sumatera, Demak di pulau Jawa, kerajaan Mataram, dan sebagainya. Dengan berdirinya kerajaan Islam di Indonesia ini, maka fase perkembangan Islam berikutnya adalah fase perkembangan Islam dan politik, yang artinya perkembangan Islam di Indonesia tidak bisa dilepaskan dari perkembangan politik.

Tumbuhnya kerajaan Islam sebagai pusat-pusat kekuasaan Islam di Indonesia ini jelas sangat berpengaruh sekali dalam proses Islamisasi/ pendidikan Islam di Indonesia, yaitu sebagai suatu wadah/ lembaga yang dapat mempermudah penyebaran Islam di Indonesia. Ketika kekuasaan politik Islam semakin kokoh dengan munculnya kerajaan-kerajaan Islam, pendidikan semakin memperoleh perhatian, karena kekuatan politik digabungkan dengan semangat para mubaligh (pengajar agama pada saat itu) untuk mengajarkan Islam merupakan dua sayap kembar yang mempercepat tersebarnya Islam ke berbagai wilayah di Indonesia.

Ada beberapa saluran proses Islamisasi di Indonesia yaitu, perdagangan, perkawinan, kesenian, sufisme, dan pendidikan. Dalam teori pendidikan dikemukakan paling tidak ada tiga hal yang ditransferkan dari si pendidik kepada si terdidik, yaitu transfer ilmu, transfer nilai, dan transfer perbuatan, dalam proses pentransferan inilah berlangsungnya pendidikan.

Pendidikan merupakan salah satu perhatian sentral masyarakat Islam baik dalam Negara mayoritas maupun minoritas. Dalam ajaran agama Islam pendidikan mendapat posisi yang sangat penting dan tinggi. Karenanya, umat Islam selalu mempunyai perhatian yang tinggi terhadap pelaksanaan pendidikan untuk kepentingan masa depan umat Islam. ${ }^{12}$

Disebabkan itulah proses pendidikan itu bisa berlangsung secara formal, nonformal, dan informal. Bila peraturan itu diatur, dilaksanakan dengan peraturan-peraturan yang ketat seperti, meteri pelajaran, waktu, tingkatan, umur, pendidik, sertifikat, dan sebagainya hal seperti inilah yang disebut sebagai pendidik formal. Sedangkan pendidik nonformal itu pendidikan yang diatur sedemikian rigitnya seperti yang disebutkan terdahulu. Dan pendidik informal itu jenis pendidikan yang yang lebih memberikan kepada proses pergaulan 
yang mendalam yang bersifat mempribadi antara si pendidik dan dengan si terdidik, seperti hubungan orang tua dengan anaknya di rumah tangga. Pada saat tertentu orang tua, tanpa disengaja dan dirancang menumbuhkan nilai-nilai (values) kepada anaknya.

Untuk mencari makna hakikat pendidikan, maka perlu dicari ciri-ciri esensial aktivitas pendidikan, sehingga dapat dipilah mana aktivitas pendidikan dan mana yang bukan, untuk itu perlu dicari unsur dasar pendidikan. Manurut pendapat Noeng Muhadjir dapat disimpulkan bahwa pendidikan dapat diteruskan sebagai aktivitas interaktif antara si pendidik dan subjek didik untuk mencapai tujuan baik dengan cara baik dalam konteks positif.

Dalam bidang kebudayaan upaya yang dilakukan oleh Sultan Agung adalah mensenyawakan unsurunsur budaya lama dengan Islam, seperti:

1. Garebeg. Upacara Garebeg diselenggarakan tiga kali dalam satu tahun kalender/penanggalan Jawa yaitu pada tanggal dua belas bulan Mulud (bulan ketiga), tanggal satu bulan Sawal (bulan kesepuluh) dan tanggal sepuluh bulan Besar (bulan kedua belas.

2. Gamelan Seketen; merupakan sebuah upacara kerajaan yang dilaksanakan selama tujuh hari. Konon asal-usul upacara ini sejak kerajaan Demak. Upacara ini sebenarnya merupakan sebuah perayaan hari kelahiran Nabi Muhammad.

3. Perhitungan tahun saka (Hindu) pada mulanya berdasarkan perjalanan matahari, tahun Saka yang telah terangka 1555 saka, tidak lagi ditambah berdasarkan perhitungan matahari, melainkan dengan hitungan perjalanan bulan, sesuai dengan tahun hijriah.

\section{PENUTUP}

Kesimpulan dari tulisan ini adalah :

1. Lembaga pendidikan Islam di Indonesia mulai tumbuh dan berkembang seiring dengan masuknya Islam sekitar abad 7 Masehi.

2. Lembaga pendidikan yang sifatnya sederhana tersebut berfungsi untuk memberikan pendidikan mendasar kepada masyarakat dan generasi Islam.

3. Proses Islamisasi mengalami kemajuan signifikan melalui jalur lembaga pendidikan Islam saat itu.

4. Lembaga pendidikan Islam di abad 7 dan 8 berkontribusi dalam Islamisasi melalui mesjid, pesantren, meunasah, rangkang, dayah dan surau.

\section{DAFTAR PUSTAKA}

Asrohah, Hanun. Sejarah Pendidikan Islam.Cet. II; Jakarta: Logos Wacana Ilmu, 2001.

Depag RI Dirjen Kelembagaan Agama Islam, Rekonstruksi Sejarah Pendidikan Islam di Indonesia, Jakarta, 2005.

Hasbullah. Sejarah Pendidikan Islam di Indonesia; Lintas Sejarah Pertumbuban dan Perkembangan.Cet.III; Jakarta: PT. Raja Grafindo Persada, 1999.

Musyrifah Sunanto. Sejarah Peradaban Islam Indonesia. Jakarta. PT. Raja Grafindo Persada, 2005.

Rukiati, Enung $\mathrm{K}$ dan Hikamawati, Fenti. Sejarah Pendidikan Islam di Indonesia. Cet. I; Bandung: Pustaka Setia, 2006.

Sunanto, Musyrifah. Sejarah Peradaban Islam Indonesia, Jakarta: PT. Raja Grafindo Persada, 2005. 
NUKHBATUL 'ULUM : Jurnal Bidang Kajian Islam

Vol. 4, No. 2 (2018) : Hal. 145-152

Website: https://journal.stiba.ac.id

ISSN : 2685-7537 (online) 2338-5251 (Printed)

Zuhairini. Sejarah Pendidikan Islam. Jakarta: Bumi Aksara, 2000.

http://www.canboyz.co.cc/2010/02/ pendidikan-Islam.html

http://limalaras.wordpress.com/2011 /01/31/asal-usul-pendidikan-

Islam-di-indonesia/

http://id.shvoong.com/books/dictio

nary/2020367-sejarah-

pertumbuhan-dan-pembaruan-

pendidikan/\#ixzz1IwJBBcfv

http://id.wikipedia.org/wiki/sejarah Indonesia 